\title{
The Synthesis, Characterization and Application of Ciprofloxacin Complexes and Its Coordination with Copper, Manganese and Zirconium Ions
}

\author{
Zhengde Tan ${ }^{1}$, Fengjiao Tan $^{2}$, Li Zhao ${ }^{2}$, Junyong Li $^{1}$ \\ ${ }^{1}$ Department of Chemistry and Chemical Engineering, Hunan Institute of Engineering, Xiangtan, China; ${ }^{2}$ Xiangtan County People’s \\ Hospital, Xiangtan, China. \\ Email: tzd0517@126.com
}

Received July $27^{\text {th }}$, 2011; revised December $26^{\text {th }}$, 2011; accepted March $16^{\text {th }}$, 2012

\begin{abstract}
In our work, ciprofloxacin was extracted from the raw material ciprofloxacin hydrochloride and coordinated with the metal ions of copper, manganese and zirconium. The procedures include the comparison of the autoclave method with the solvothermal method, synthesizing the corresponding complexes and conducting antibacterial test on nearly 20 kinds of bacteria. It is shown that under the condition of $\mathrm{PH} 1$ and $110^{\circ} \mathrm{C}-116^{\circ} \mathrm{C}$, the autoclave method and solvothermal method can be utilized to obtain the ciprofloxacin complexes with $\mathrm{Cu}^{2+}, \mathrm{Mn}^{2+}$ and $\mathrm{Zr}^{2+}$ as the metal ligands after reacting for 8 hours. The raw material, ligands and monocrystals were characterized by IR, DSC, UV and fluorescence spectrum. Meanwhile a great number of antibacterial tests were carried out, revealing favorable bacteriocidal properties of the resulting complexes.
\end{abstract}

Keywords: Ciprofloxacin; Ligand; Characterization; Antibacterial

\section{Introduction}

Quinolone antibacterial drugs [1] has many characteristics, such as broad antibacterial spectrum [2-4], high bactericidal activity, low toxicity and unique mechanism. As one of the most important antibiotics, it is widely used in various infectious diseases in clinical treatment. Among the first generation, the most improtant antibiotics are nalidixic acid and piromidic acid; they have a remarkable influence on most gram-negative bacteria, but almost no influence on gram-positive bacteria and pseudomonas aeruginosa. On behalf of the second generation Quinolone antibacterial drugs, Cinoxacin and pipemidic acid inhibits gram-negative bacteria while improving bactericidal activity compared with the first generation [5,6]. Norfloxacin, enoxacin, ciprofloxacin and ofloxacin are the representatives of the third generation. The third generation quinolone has wide antimicrobial spectrum, except for having strong bacteriostasis for gram-negative bacteria, it also shows the strong activity for gram-positive bacteria. However, there are still many problems and challenges have not been settled regarding drug function mechanism, drug resistance, further development and etc. Because of the exceptional position in medicine and beneficial biological performance of metal ions, it has great theoretical and practical significance for the devel- opment and application of quinolones and new metallic anticancer compounds as well as promote the complexation of drug ligands or synthesis of metallic compounds in terms of investigation on the mechanism and inorganic medicine [7].

Currently, most research focus on the structure of quinolone-metal complexes, however, the research on the nature of complexes is neither comprehensive nor deep [8-11]. The synthesis, structure and physicochemical properties of quinolone-transition metal complexes are fully studied and there are also reports on the biological properties. But these researches mainly target at the norfloxacin and cinoxacin metal complexes. So far little material is available on transition metal complexes of ciprofloxacin (CPFX). Although much initial work has been done to deal with the subject, researches in this field are far from intensive and systematic, not to mention that no pronounced progress has been made. Therefore, it is absolutely necessary to further study this kind of promising antibiotics. Herein, we report the synthesis and crystal structure of the title complexes, researching the coordination way of ciprofloxacin and metal ions and obtaining the new material and new use from activity test in-vitro.

In this paper, autoclave method, hydrothermal synthesis and direct mixing with the solvent were utilized to 
synthesize all kinds of complexes, with ciprofloxacin deeply associated with physiological function as the transition metals. The coordination chemistry of the physiochemical properties of the complexes are investigated by IR, fluorescence spectrum UV-Visable, DSC and etc. And the subsequent bacteriostasis tests indicate the exceptional performance of the metal complexes.

\section{Experimental Section}

\subsection{Main Reagents and Equipment}

Capsule of ciprofloxacin hydrochloride, obtained by HPGC Group General Pharmaceutical Factory. Acetic acid (AR), provided by Shantou Xilong Chemical Co., Ltd. Copper sulfate dihydrate (AR) and zirconium oxychloride (AR), purchased from the Development Center of Tianjin Kermel Reagent Co., Ltd. Manganese chloride(AR), offered by Tianjin Tianyida chemical Co., LTD. Ethanol (AR), offered by Tianjin Damao Reagent Factory, acetone (AR) by Tianjin Fuyu Fine Chemical Industry Co., Ltd and hydrochloride (AR) by Hengyang Xunyuan Chemical Reagent Co., Ltd.

Magnetic agitator with thermostat heater, DF-101S, Gongyi Yuhua Instrument Factory high-pressure reaction kettle, KF-20 ml, Xi'an Taikang Biological Science and Technology Co., Ltd; vacuum pump with circulating water system, SHZ-D(III), Gongyi Yuhua Instrument Co., Ltd; vacuum drying oven, DZF-250, Zhengzhou Greatwall Scientific Industrial and Trading Co., Ltd; fluorospectro photometer, 960MC, Shanghai Precision and Scientific Instrument Co., Ltd; Fourier infrared spectrometer, AVATAR370, Thermo Nicolet Corp in America.; differential scanning calorimeter, DSC 200 F3, Netzsch Scientific Instruments Co., Ltd; Ultraviolet spectrometer, UV8100, Shanghai Jiashi Scientific Instrument Co., Ltd.

\subsection{Experimental Procedures}

\subsubsection{Extraction of Ciprofloxacin}

The raw material, ciprofloxacin hydrochloride, was deprived of hydrochloride and went through other reactions to obtain pure ciprofloxacin. The reaction is Figure 1.

After grinding the chemical granules, ciprofloxacin hydrochloride (45.963 g) was put into a beaker $(250 \mathrm{ml})$. At the temperature of $50^{\circ} \mathrm{C}$, ammonia water $(1 \mathrm{~mol} / \mathrm{L})$ was slowly added till the solution became neutral and the solution was stirred for 15 minutes. The stirred solution was filtered and put into the vacuum drying oven for 6

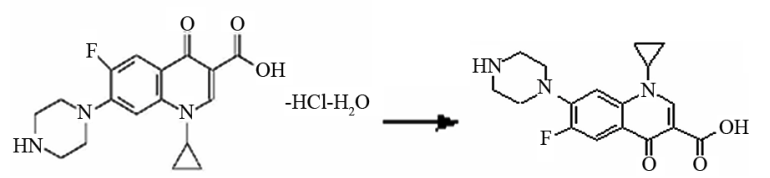

Figure 1. Preparation of ciprofloxacin. hours after removal of filter cake. Finally, the dried ciprofloxacin product was grinded into powder, weighing $46.27 \mathrm{~g}$, ready for the following synthesis.

\subsubsection{Synthesis of Ciprofloxacin Copper}

Add a certain amount of hydrochloric acid $(1 \mathrm{~mol} / \mathrm{L})$ into a beaker with ciprofloxacin (2.5 g). Fully stirring was conducted to make ciprofloxacin dissolve. When $\mathrm{PH}$ value was kept around 1, copper sulfate dehydrate was added (AR, $0.77 \mathrm{~g}$ ) into the solution, then stirred it for half an hour in a $75^{\circ} \mathrm{C}$ water bath. The operation will be done in two ways. The first is to pour the solution into the autoclave in the oil bath and oxygen-proof reaction was conducted for 8 hours at $115^{\circ} \mathrm{C}$. Then the solution cooled to room temperature with heaters off, and was kept overnight. The solid was filtered off, washed with water and placed in the vacuum oven to obtain the product. The second is to pour the resulting solution in a three-necked round-bottom flask and install the condensation reflux unit. Likewise, the reaction was conducted for 8 hours at $115^{\circ} \mathrm{C}$ and then cooled to room temperature. The solution with white and flocculent upper side was filtered, washed and dried in the vacuum oven to obtain the resulting chemicals.

\subsubsection{Synthesis of Ciprofloxacin Zirconic}

Sodium hydroxide $(1 \mathrm{~mol} / \mathrm{L})$ was added to ciprofloxacin (2.5 g) and the mixture was stirred to make ciprofloxacin dissolve in the solution. Zirconium oxychloride (1.61 g) was added at $\mathrm{PH}$ value of 12 and stirred continuously in the $75^{\circ} \mathrm{C}$ water bath for another half an hour. The solution turned white and pasty and poured it into a threenecked round-bottom flask (250 ml). After installation of the condensation reflux unit, the solution was reacted at $110^{\circ} \mathrm{C}$ for 8 to 10 hours, then cooled to room temperature with colorless solution in the upper side and white sediment in the lower side. The solid was filtered off and washed with water, dried in the vacuum oven and grinded into the resulting powder.

\subsubsection{Synthesis of Ciprofloxacin Manganese}

A certain amount of Hydrochloric acid $(1 \mathrm{~mol} / \mathrm{L})$ was added into ciprofloxacin (2.5 g) and the mixture was stirred to make ciprofloxacin dissolve in the solution. $1.57 \mathrm{~g} \mathrm{MnCl}_{2}$ was added at $\mathrm{PH}$ value of 1 and stirring was done in the $75^{\circ} \mathrm{C}$ water bath for half an hour. The solution turned white and pasty and was poured into a three-necked round- bottom flask. After installation of the reflux unit, the solution was reacted at $110^{\circ} \mathrm{C}$ for 8 to 10 hours, (the solution begins to turn yellow during 20 min reaction) then cooled to room temperature with colorless solution in the upper side and tan lotion in the lower side. The solid was filtered off and washed with 
the water, then dried in the vacuum oven and grinded into the resulting powder.

\subsection{Characterization of the Complexes}

\subsubsection{Testing Analysis of Infrared Spectrometer (IR)}

The samples (raw materials and synthesized complexes) were grinded with potassium bromide in the proportion of 1:100. The mixture was then pressed into plates, which was tested by means of Fourier infrared spectrometer. The spectra were collected and available in the Result and Discussion section.

\subsubsection{Testing Analysis of Differential Scanning Calorimeter (DSC)}

The calorimetric analysis of as-prepared $0.0050 \mathrm{~g}$ samples (raw materials or synthesized complexes) which measured by the electronic balance, accurate to $0.0001 \mathrm{~g}$, it was detected in NETZSCH DSC 200 F3 calorimeter (with nitrogen as the shielding gas, gas speed of 260 $\mathrm{ml} / \mathrm{min}$, sampling rate of $200.00 \mathrm{pts} / \mathrm{min}$ and heating rate of $20.000 \mathrm{~K} / \mathrm{min})$. Refer to the Result and Discussion for the spectrogram.

\subsubsection{Testing Analysis of Ultraviolet Spectrometer (UV)}

The as-prepared samples (raw materials and synthesized complexes) were dissolved in disodium hydrogen phosphate $(0.5 \mathrm{~mol} / \mathrm{l})$ and sodium dihydrogen phosphate $(0.5$ $\mathrm{mol} / \mathrm{l})$. Acetic acid was also added to assist the dissolution and keep a constant volume of $50 \mathrm{ml}$. According to the literature, the scanning spectrum was determined between $200 \mathrm{~nm}$ and $400 \mathrm{~nm}$, which can be seen in the Result and Discussion section.

\subsubsection{Testing Analysis of Fluorescence Spectrometer}

The as-prepared samples (raw materials and the resulting complexes) were dissolved in disodium hydrogen phosphate $(0.5 \mathrm{~mol} / \mathrm{l})$ and sodium dihydrogen phosphate $(0.5$ $\mathrm{mol} / \mathrm{l})$. Acetic acid was also added to assist the dissolution and to keep a constant volume of $50 \mathrm{ml}$. Fluorescence spectra were collected using a $960 \mathrm{MC}$ fluorospectro photometer for the whole wavelength. The scanning spectrum of the complexes was thus determined from the range of $370 \mathrm{~nm}$ to $450 \mathrm{~nm}$, hereby find out the maximum absorption wavelength. Refer to the Result and Discussion for the details.

\section{Results and Discussion}

\subsection{Analysis of the Main Influence Parameter}

\subsubsection{Effect of the $\mathbf{p H}$ on the Solubility}

The $\mathrm{pH}$ value can be adjusted by changing the solvent as shown in Table 1. It is concluded from Table 1 that copper and manganese can well dissolve in hydrochloric acid when $\mathrm{pH}$ value is 1 , while zirconium can be well dissolved in hydrochloric acid when $\mathrm{pH}$ value is 12 .

\subsubsection{Effect of Temperature}

It is summarized from Tables 2 and $\mathbf{3}$ that the best reflux temperature for aqueous solution is $115^{\circ} \mathrm{C}$, while the most appropriate reaction temperature for autoclave method is around $110^{\circ} \mathrm{C}$. Therefore, the optimum temperature should be controlled at $115^{\circ} \mathrm{C}$.

Table 1. Data tables of $\mathrm{pH}$ value and medium.

\begin{tabular}{|c|c|c|c|}
\hline $\mathrm{pH}$ & Metal ions & Medium (1 mol/l) & Results show \\
\hline 10 & $\begin{array}{l}\text { Copper sulfate } \\
\text { dihydrate }\end{array}$ & Sodium hydroxide & $\begin{array}{l}\text { Poorly dissolved, less } \\
\text { product }\end{array}$ \\
\hline 1 & $\begin{array}{l}\text { Copper sulfate } \\
\text { dihydrate }\end{array}$ & Hydrochloric acid & $\begin{array}{l}\text { Well dissolved, good } \\
\text { product }\end{array}$ \\
\hline 4 & $\begin{array}{l}\text { Copper sulfate } \\
\text { dihydrate }\end{array}$ & acetic acid Sodium & $\begin{array}{l}\text { Poorly dissolved,less } \\
\text { product, inconsistent } \\
\text { properties }\end{array}$ \\
\hline 11 & $\begin{array}{l}\text { Manganese } \\
\text { chloride }\end{array}$ & hydroxide & $\begin{array}{c}\text { Almost undissolved,less } \\
\text { product }\end{array}$ \\
\hline 1 & $\begin{array}{l}\text { Manganese } \\
\text { chloride }\end{array}$ & Hydrochloric acid & $\begin{array}{l}\text { Well dissolved,good } \\
\text { product }\end{array}$ \\
\hline 4 & $\begin{array}{l}\text { Manganese } \\
\text { chloride }\end{array}$ & acetic acid & $\begin{array}{l}\text { Almost undissolved,less } \\
\text { product }\end{array}$ \\
\hline 12 & $\begin{array}{l}\text { Zirconium } \\
\text { oxychloride }\end{array}$ & Sodium hydroxide & $\begin{array}{l}\text { Well dissolved,good } \\
\text { product }\end{array}$ \\
\hline 1 & $\begin{array}{l}\text { Zirconium } \\
\text { oxychloride }\end{array}$ & Hydrochloric acid & $\begin{array}{l}\text { Poorly dissolved,less } \\
\text { product }\end{array}$ \\
\hline 4 & $\begin{array}{l}\text { Zirconium } \\
\text { xychloride }\end{array}$ & acetic acid & $\begin{array}{c}\text { Almost undissolved,less } \\
\text { product }\end{array}$ \\
\hline
\end{tabular}

Table 2. Aqueous solution reflux temperature control.

\begin{tabular}{ccccc}
\hline Temperature $\left({ }^{\circ} \mathrm{C}\right)$ & 90 & 100 & 105 & 115 \\
\hline $\begin{array}{c}\text { Ciprofloxacin } \\
\text { copper }\end{array}$ & Invalid & $\begin{array}{c}\text { Less and } \\
\text { worse product }\end{array}$ & $\begin{array}{c}\text { worse } \\
\text { product }\end{array}$ & $\begin{array}{c}\text { More and } \\
\text { better } \\
\text { product } \\
\text { Ciprofloxacin } \\
\text { manganese }\end{array}$ \\
$\begin{array}{c}\text { Ciprofloxacin } \\
\text { zirconium }\end{array}$ & Invalid & $\begin{array}{c}\text { Less and } \\
\text { worse product }\end{array}$ & $\begin{array}{c}\text { worse } \\
\text { product }\end{array}$ & $\begin{array}{c}\text { better } \\
\text { product } \\
\text { Invalid } \\
\text { Lore and } \\
\text { better } \\
\text { product }\end{array}$ \\
\hline
\end{tabular}

Table 3. Exploration of high pressure reactor method temperature control table.

\begin{tabular}{|c|c|c|c|}
\hline Temperature $\left({ }^{\circ} \mathrm{C}\right)$ & 100 & 110 & 120 \\
\hline Ciprofloxacin copper & $\begin{array}{l}\text { Less and worse } \\
\text { product }\end{array}$ & $\begin{array}{c}\text { More and } \\
\text { better product }\end{array}$ & $\begin{array}{c}\text { Less and worse } \\
\text { product }\end{array}$ \\
\hline $\begin{array}{l}\text { Ciprofloxacin } \\
\text { manganese }\end{array}$ & $\begin{array}{c}\text { Less and worse } \\
\text { product }\end{array}$ & $\begin{array}{c}\text { More and } \\
\text { better product }\end{array}$ & $\begin{array}{c}\text { Less but better } \\
\text { product }\end{array}$ \\
\hline $\begin{array}{l}\text { Ciprofloxacin } \\
\text { zirconium }\end{array}$ & $\begin{array}{l}\text { Less and worse } \\
\text { product }\end{array}$ & $\begin{array}{c}\text { More and } \\
\text { better product }\end{array}$ & $\begin{array}{c}\text { Less but better } \\
\text { product }\end{array}$ \\
\hline
\end{tabular}




\subsection{IR Spectrum}

The infrared spectra of ciprofloxacin, ciprofloxacin copper, ciprofloxacin manganese and ciprofloxacin zirconnium are shown in Figures 2-4, respectively.

Among the ciprofloxacin vibrations, those at 1628.81, 1507.34 and $1473.82 \mathrm{~cm}^{-1}$ are assigned to vibration absorption of the $\mathrm{CH}_{2}$ on the benzene ring. The 1721 and $3403 \mathrm{~cm}^{-1}$ stretching vibrations are attributed to carbonyl and hydroxyl in a carboxyl group, respectively. The 1396 and $941 \mathrm{~cm}^{-1}$ vibrations correspond to the bending of $\mathrm{O}-\mathrm{H}$,and around $740 \mathrm{~cm}^{-1}$ indicates the absorption peak of secondary amine. Overall, the recorded spectrum is indicative of ciprofloxacin, since it is similar to standard spectrum of ciprofloxacin containing hydrogen chloride but no aggregates.

It can be observed in Figure 3 that the peak in 1700 $\mathrm{cm}^{-1}$ disappears while peak in $3400 \mathrm{~cm}^{-1}$ remains compared with the standard spectrum, which accounts for the association effect between copper and carbonyl.

From Figure 4, two absorption peaks of N-H appear at around $3400 \mathrm{~cm}^{-1}$, indicating of the association between manganese and carbonyl.

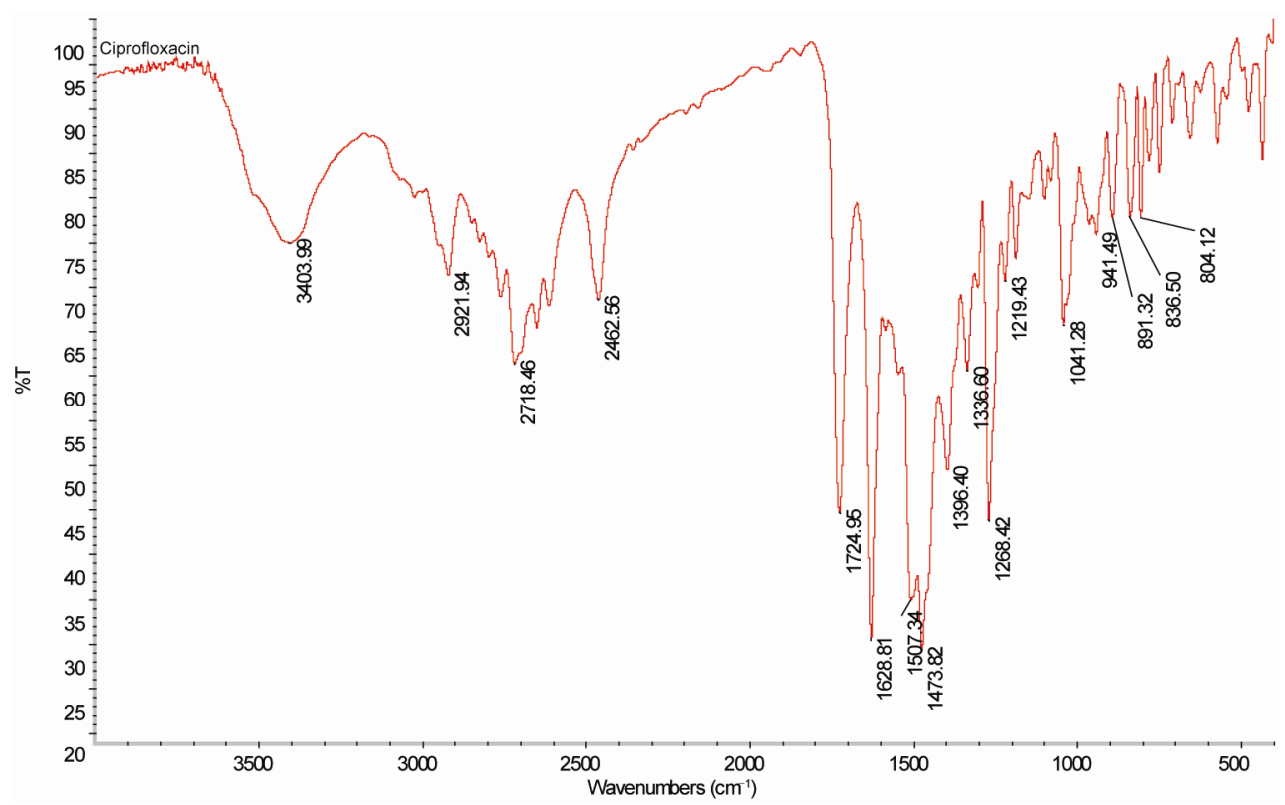

Figure 2. Infrared spectrum of ciprofloxacin.

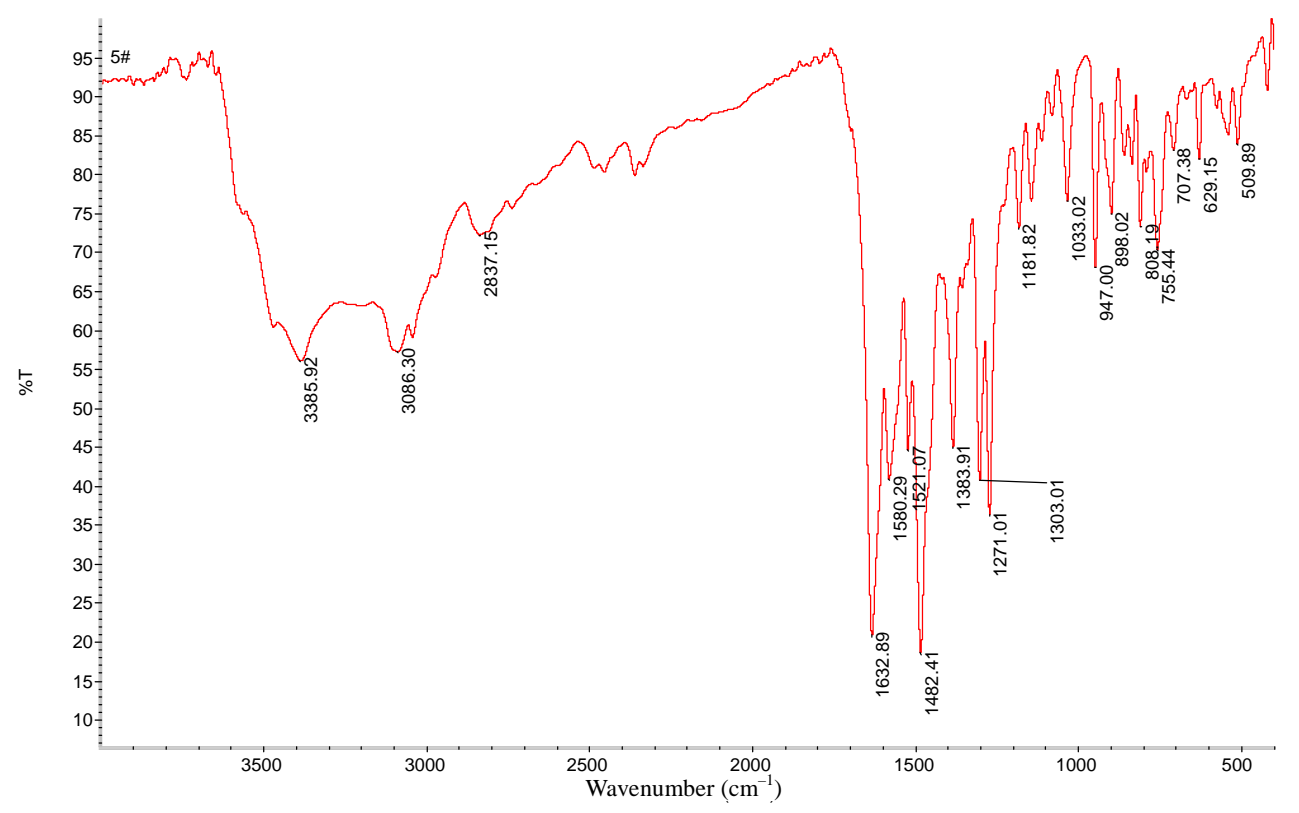

Figure 3. Infrared spectra of ciprofloxacin copper. 
Compared with standard spectra, From Figure 5, the peak in $1700 \mathrm{~cm}^{-1}$ disappears while the peak in 3400 $\mathrm{cm}^{-1}$ remains, which may be assigned to the association between zirconium and carbonyl, besides, the absence of vibration peaks of C-H between 2500 and $3000 \mathrm{~cm}^{-1}$ is associated with the association of zirconium.

\subsection{DSC}

The weight of as-prepared samples is listed in Tables 4 and 5.

From Figure 6, the endothermic peak of ciprofloxacin may account for the intramolecular change while the exothermic peak is due to the formation of new intermolecular or intramolecular bonds

From Figure 7, the strong exothermic peak at $345.4^{\circ} \mathrm{C}$ is associated with the formation of new intermolecular hydrogen bonds and several spikes appear at the peak because of instability of synthetic compound.

From Figure 8, the $331.5^{\circ} \mathrm{C}$ peak is associated with melting process of metal complex, and the existence of metal ions leads to increased melting point. The $363.7^{\circ} \mathrm{C}$ exothermic peak demonstrates the formation of new intermolecular bonds in the melt. Therefore, metal ions were coordinated onto ciprofloxacin during this process.

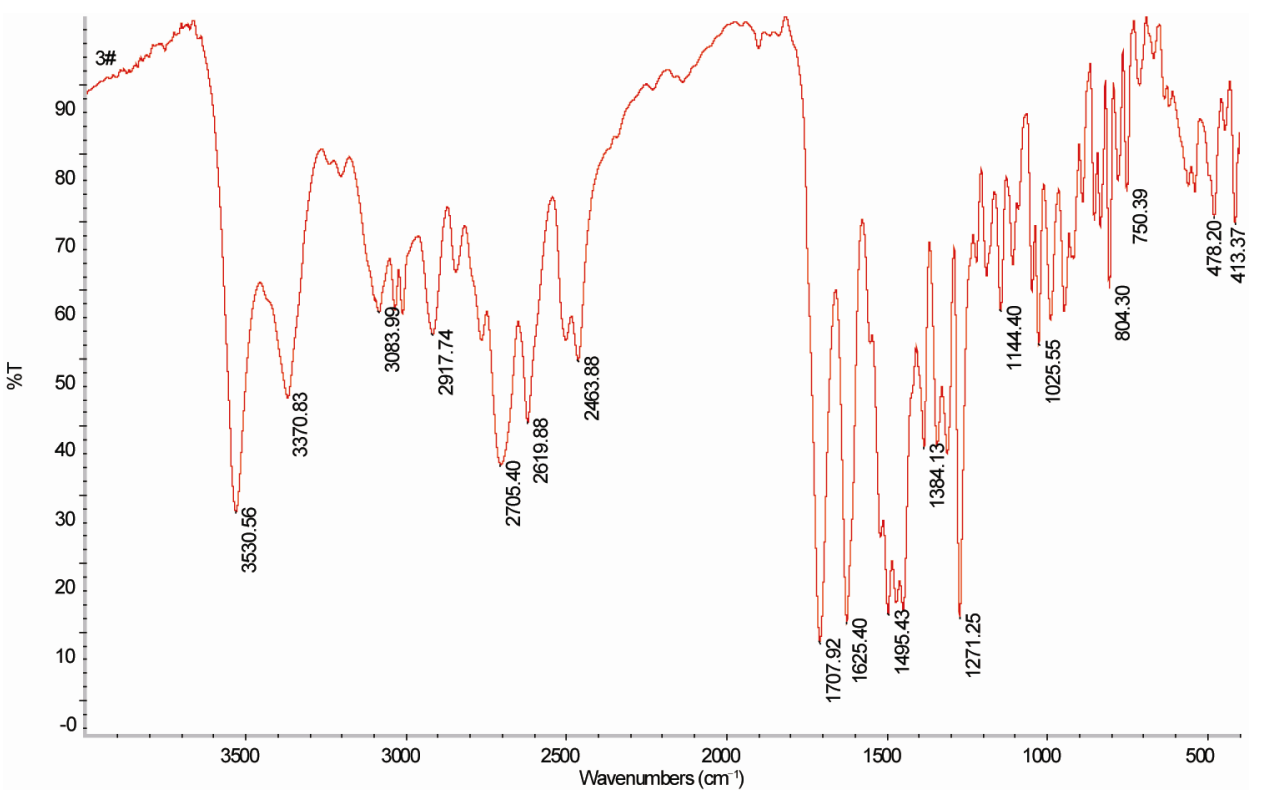

Figure 4. Infrared spectra of ciprofloxacin manganese.

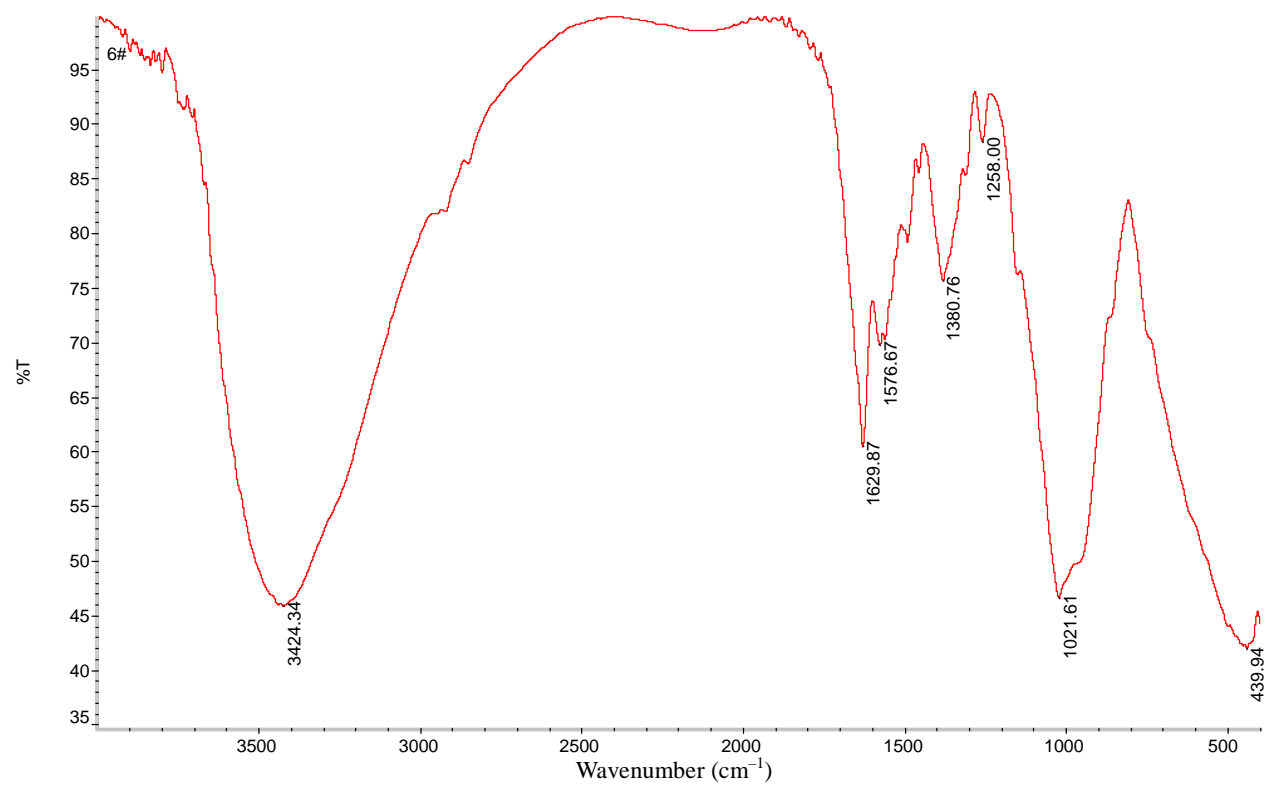

Figure 5. Infrared spectra of ciprofloxacin zirconium. 
Table 4. Sample quality.

\begin{tabular}{ccccc}
\hline Designatin & Ciprofloxacin & Ciprofloxacin copper & Ciprofloxacin manganese & Ciprofloxacin zirconium \\
\hline Weight (g) & 0.0050 & 0.0051 & 0.0050 & 0.0049 \\
\hline
\end{tabular}

Table 5. Temperature list.

\begin{tabular}{|c|c|c|c|c|c|c|c|c|}
\hline Mode & Temp $\left({ }^{\circ} \mathrm{C}\right)$ & Heating rate $(\mathrm{K} / \mathrm{min})$ & Sampling rate (pts/min) & Time (hh:mm) & STC & $\mathrm{P} 2$ & PG & Co \\
\hline Waiting mode (heating) & 20.0 & 40.000 & & & 1 & 1 & 1 & 1 \\
\hline Waiting mode (stabilizing) & 20.0 & & & 02:00 & 1 & 1 & 1 & 1 \\
\hline Dynamic & 450.0 & 20.000 & 200.00 & 00:21 & 1 & 1 & 1 & 1 \\
\hline Urgent & 460.0 & & & & & 1 & 1 & 1 \\
\hline End of waiting mode (heating) & 20.0 & 40.000 & & 00:10 & 1 & 1 & 1 & 1 \\
\hline End of waiting mode (stabilizing) & 20.0 & & & 02:00 & 1 & 1 & 1 & 0 \\
\hline
\end{tabular}

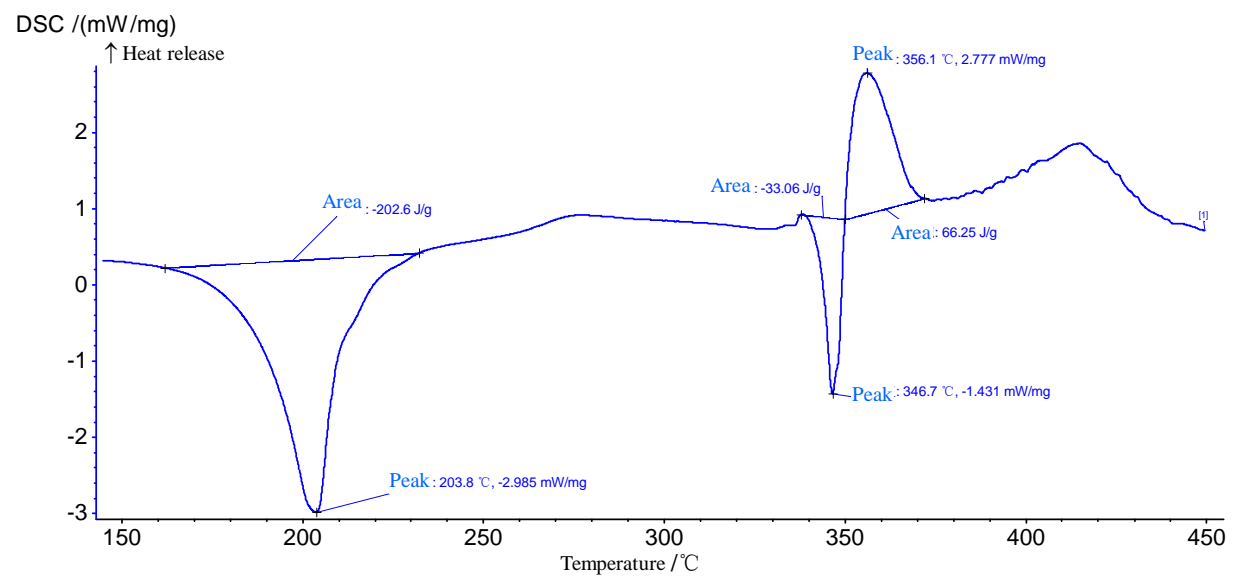

Figure 6. DSC diagram of ciprofloxacin.

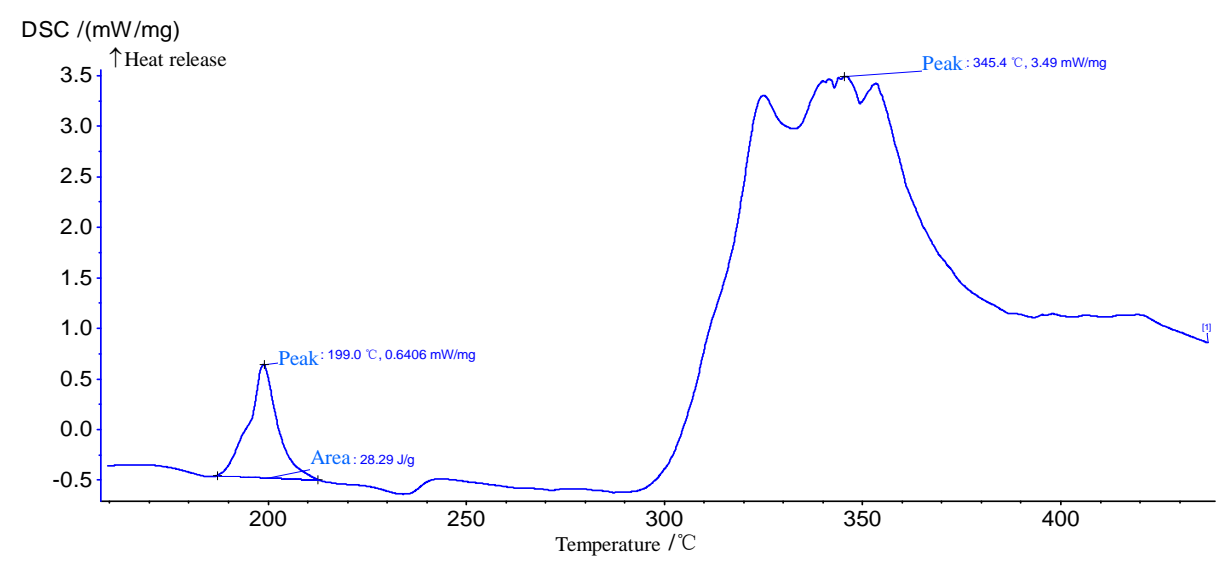

Figure 7. DSC diagram of ciprofloxacin copper.

From Figure 9, the front is a water peak, it is to be ignored, and then there is no peak, so can't analyse it.

\subsection{UV Analysis}

As Figures 10-13 show, it can be concluded from the three graphs above that the peaks in the UV spectra of the three complexes show a red shift with varying degree, compared with that of the pure ciprofloxacin. In three metal complexes, both dispersive charge and metallic tracks contribute to the convenient transfer of the electrons, leading to weakened absorption of ultraviolet light and obvious red shift. So conclusion can be drawn that metal ions have an influence on the UV absorption and an indirect reaction occurs between metal ions and ciprofloxacin, resulting in red shift. 


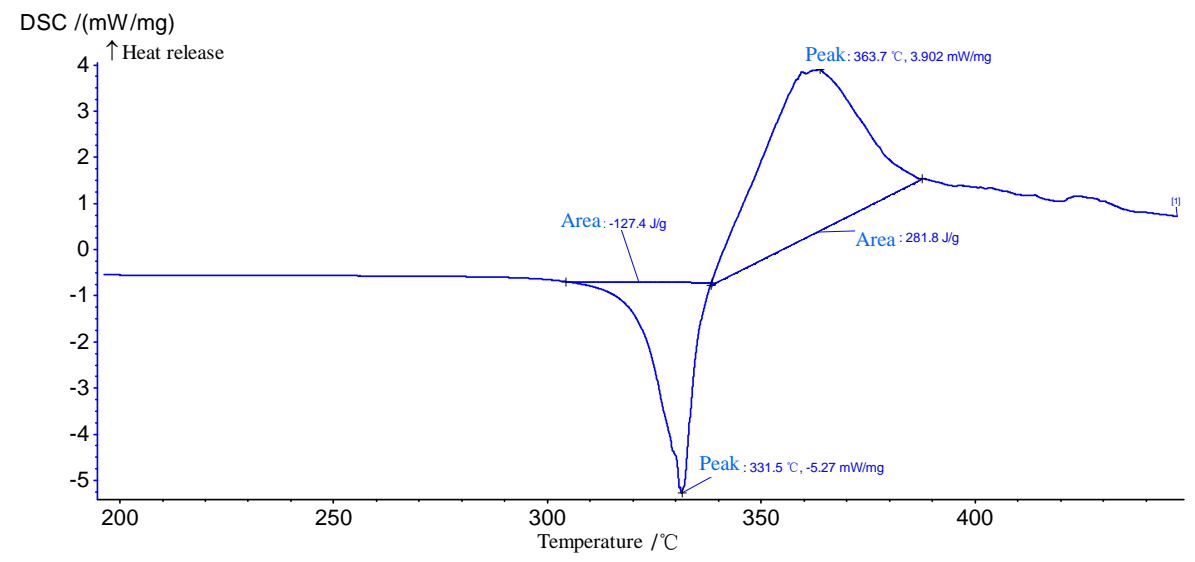

Figure 8. DSC graph of ciprofloxacin manganese.

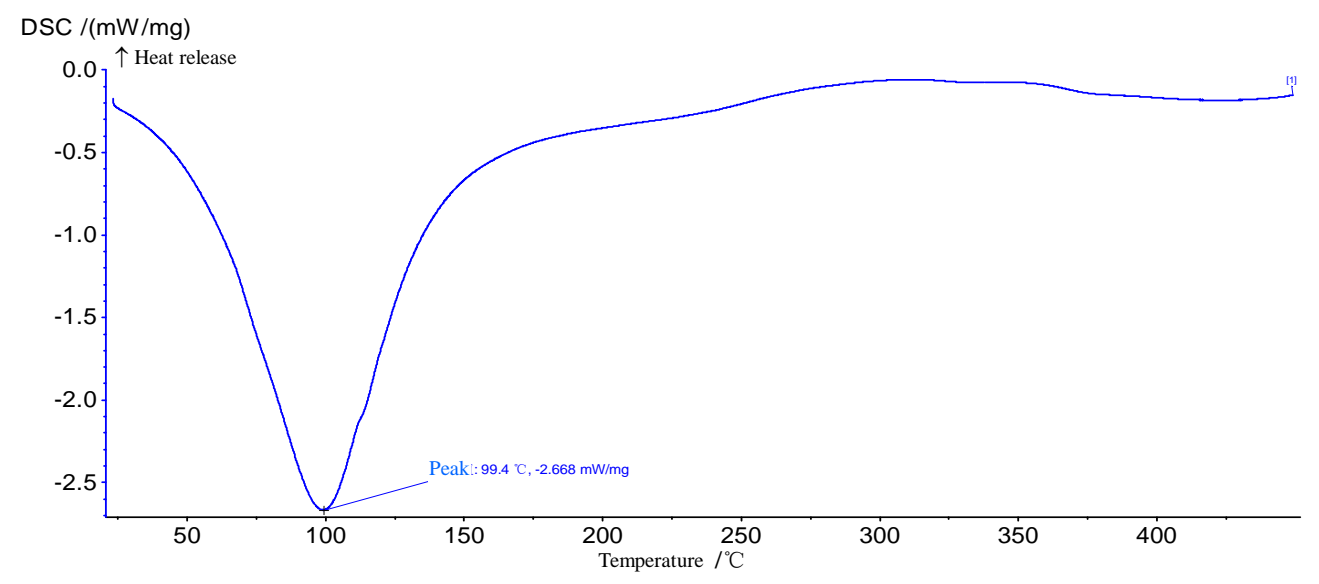

Figure 9. DSC graph of ciprofloxacin zirconium.

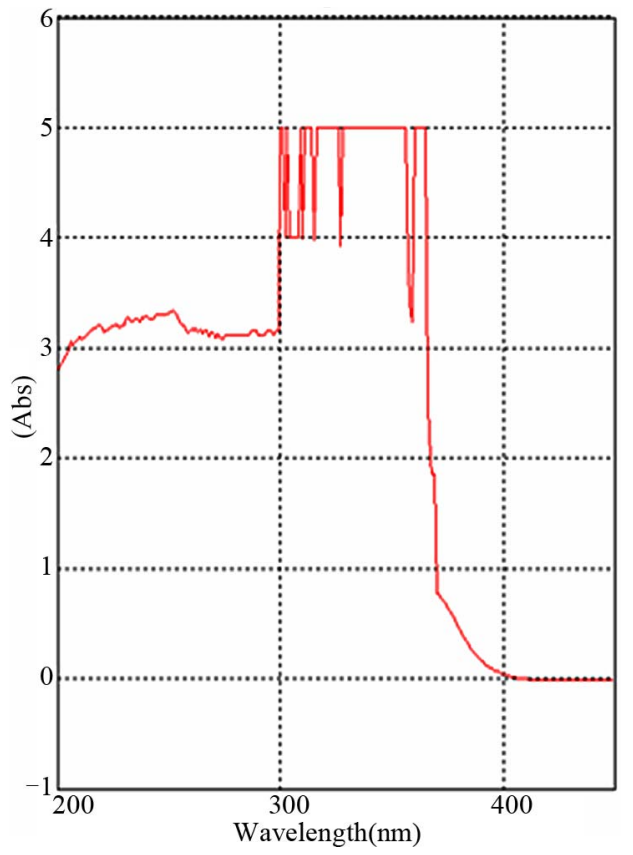

Figure 10. UV-spectrum of ciprofloxacin.

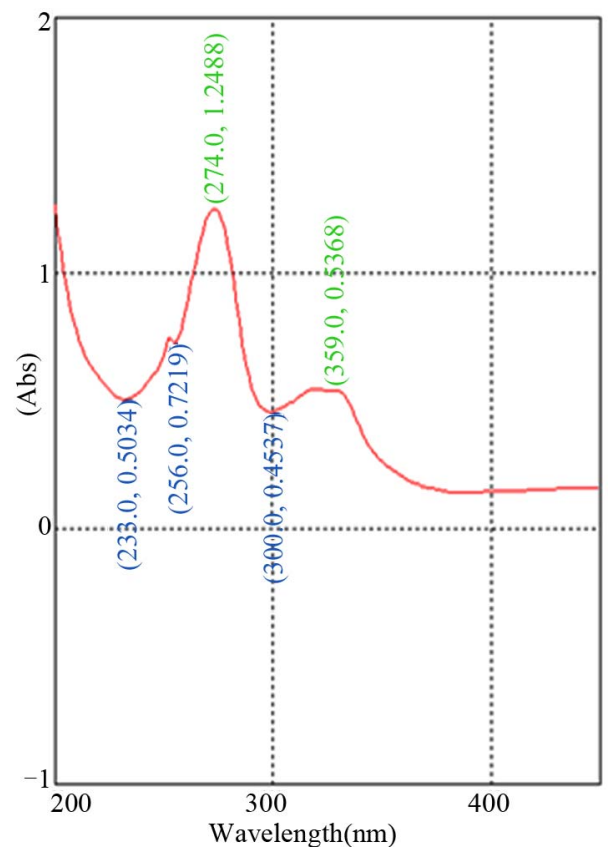

Figure 11. UV-spectrum of ciprofloxacin copper. 


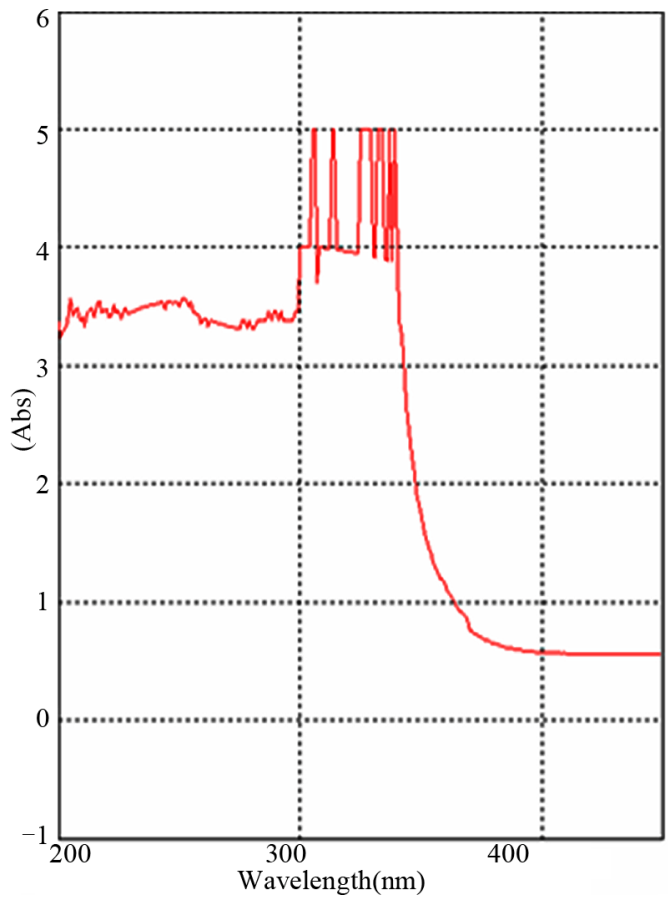

Figure 12. UV-spectrum of ciprofloxacin manganese.

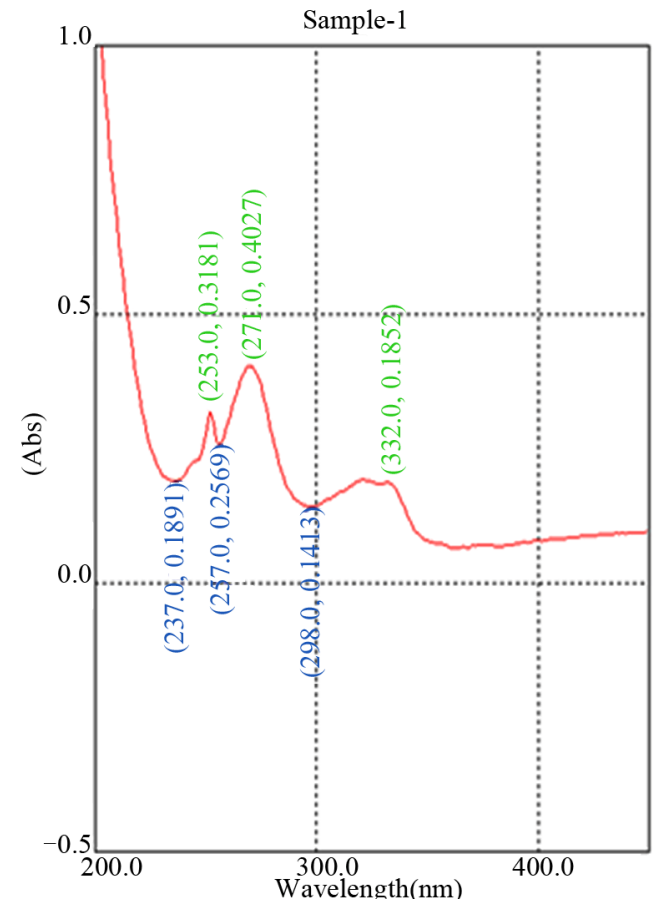

Figure 13. UV-spectrum of ciprofloxacin zirconium.

\subsection{Fluorescence Spectral Analysis}

It is shown in Table 6 that red shift in fluorescence spectral of complex was observed due to existence of metal ions. It can be concluded from this phenomenon that metal ions were successfully coordinated to ciprofloxacin despite of fluctuated fluorescence intensity caused by the impurity. Overall, metal ions make it more apparent for the fluorescence to quench.

\subsection{In Vitro Antimicrobial Activity Test}

Parameters of MIC (minimal inhibitory concentration) [12] in the antibacterial test are presented in the Table 7.

It can be concluded from Table 7 that the three complexes have an inhibiting effect on escherichia coli, staphylococcus aureus and staphylococcus epidermidis at low concentration, but remain inactive towards streptococcus pneumoniae and klebsiella pneumoniae. In general, metal complexes of ciprofloxacin exhibit exceptional antimicrobial properties [13,14].

\section{Conclusion}

As one of the third-generation antimicrobial quinolones, ciprofloxacin, possessing broad-spectrum antimicrobial activity, has wide application in clinical treatment of infections and diseases caused by gram-negative bacteria and gram-positive bacterial. In our work, ciprofloxacin was extracted from the raw material ciprofloxacin hydrochloride and coordinated with the metal ions of copper, manganese and zirconium. The procedures include

Table 6. Data sheet of fluorescence spectral.

\begin{tabular}{cccccc}
\hline Type & PH & SENS & Y & $\lambda_{\max }(\mathrm{nm})$ & Fluorescence intensity \\
\hline $\mathrm{HN}$ & 4.0 & 1 & 2 & 445 & 52.1 \\
$\mathrm{H}-\mathrm{Cu}$ & 6.2 & 1 & 2 & 380 & 76.5 \\
$\mathrm{H}-\mathrm{Mn}$ & 6.4 & 1 & 1 & 375 & 56.4 \\
$\mathrm{H}-\mathrm{Zr}$ & 6.2 & 1 & 2 & 375 & 90.6 \\
\hline
\end{tabular}

Table 7. In vitro antibacterial activity data sheet.

\begin{tabular}{|c|c|c|c|}
\hline Strains & $\begin{array}{l}\text { Copper } \\
\text { (MIC) }\end{array}$ & $\begin{array}{l}\text { Manganese } \\
\text { (MIC) }\end{array}$ & $\begin{array}{l}\text { Zirconium } \\
\text { (MIC) }\end{array}$ \\
\hline Streptococcus pneumoniae 70 & $>128$ & $>128$ & $>128$ \\
\hline Streptococcus pneumoniae 9798 & $>128$ & $>128$ & $>128$ \\
\hline Streptococcus pyogenes A12 & $>128$ & 32 & $>128$ \\
\hline Staphylococcus aureus 9616 & 16 & 4 & 16 \\
\hline $\begin{array}{l}\text { Staphylococcus epidermidis } \\
9726\end{array}$ & 16 & 16 & 16 \\
\hline Escherichia coli ATCC25922 & 16 & 16 & 16 \\
\hline Escherichia coli 834 & 16 & 8 & 8 \\
\hline $\begin{array}{c}\text { Pseudomonas aeruginosa } \\
\text { ATCC27853 }\end{array}$ & 32 & $>128$ & $>128$ \\
\hline Klebsiella pneumoniae 14 & $>128$ & $>128$ & $>128$ \\
\hline Salmonella typhi H901 & 16 & 16 & 16 \\
\hline
\end{tabular}


comparison the autoclave method with the solvothermal method, synthesize the corresponding complexes, and conduct antibacterial test on nearly 20 kinds of bacteria. It is shown that under the condition of $\mathrm{PH} 1$ and $116^{\circ} \mathrm{C}$, the autoclave and solvothermal method can be utilized to obtain the ciprofloxacin single crystal after reacting for 8 hours. Under $\mathrm{PH} 1,115^{\circ} \mathrm{C}$ and $\mathrm{PH} 12,110^{\circ} \mathrm{C}$ respectively, the test combined corresponding manganese and zirconnium coordination compound and adopted solvent volatilization method to obtain corresponding ciprofloxacin single crystal. The raw materials and ligands were characterized by IR, DSC, UV-Visable and fluorescence spectrum. Meanwhile a great number of antibacterial tests were carried out. Three kinds of ciprofloxacin metal ion coordination compound can effectively inhibit the growth of bacteria, among them ciprofloxacin manganese has the most effective antibacterial properties.

\section{Acknowledgements}

The authors acknowledge the Education Department of Hunan Province [Xiang Norimichi (2010).243] for supporting this work.

\section{REFERENCES}

[1] M. Gellet, K. Mizuuchi, M. H. O’Dea and H. A. Nash, "DNA Gyrase: An Enzyme That Introduces Superhelical Turns into DNA,” Proceedings of the National Academy of Sciences USA, Vol. 73, No. 11, 1976, pp. 3872-3878.

[2] T. D. Gootz, J. F. Larrenll and J. A. Suteliffe, "Inhibitory Effects of Quinolone Antibacterial Agents on Eucaryofic Topoisomerases and Related Test Systems," Antimicrobial Agents and Chemotherapy, Vol. 34, No. 1, 1990, pp. 8-16.

[3] C. A. Lipinski, "Drug-Like Properties and the Causes of Poor Solubility and Poor Permeability," Journal of Pharmacological and Toxicological Methods, Vol. 44, No. 1, 2000, pp. 235-249. doi:10.1016/S1056-8719(00)00107-6

[4] K. Hoshino, A. Kitamura, I. Morrissey, K. Sato, J. Kato and H. Ikeda, "Comparison of Inhibition of Escherichia Coli Topoisomerase IV by Quinolones with DNA Gyrase Inhibition," Antimicrobial Agents and Chemotherapy, Vol. 38, No. 11, 1994, pp. 2623-2628.

[5] F. Anaya-Velázquez, F. Padilla-Vaca, S. Arias-Negrete and G. Mendoza-Díaz, "In Vitro Activity of Nalidixic
Acid and Its Iron (III) Complex on Entamoeba histolytica," Transactions of the Royal Society of Tropical Medicine and Hygiene, Vol. 83, No. 3, 1989, pp. 344350.

[6] G. P. Wang, X. C. Fu and L. G. Zhu, "Preparation, Crystal Structure and Antineoplastic Activity of Copper (II)Fluoroquinolone-Phenanthroline Mixed-Ligand Complex," Chinese Journal of Inorganic Chemistry, Vol. 19, No. 9, 2003, pp. 78- 84.

[7] S. Lecomte, M. H. Baron, M. T. Chenon, C. Coupry and N. J. Moreau, "Effect of Magnesium Complexation by Fluoroquinolones on Their Antibacterial Properties," Antimicrobial Agents and Chemotherapy, Vol. 38, 1994, pp. 2810-2818.

[8] I. Turel, I. Leban, G. Klintschar, N. Bukovec and S. Zalar, "Synthesis Crystal Structure, and Characterization of Two Metal-Quinolone Compounds,” Journal of Inorganic Biochemistry, Vol. 66, 1997, pp. 77-84.

[9] I. Turel, I. Leban and N. Bukovec, "Synthesis, Characterization, and Crystal Structure of a Copper(II) Complex with Quinolone Family Member (Ciprofloxacin): Bis(1)cyclopropyl-6-fluoro-14-dihydro-4-OXO-7-piperazin-1ylquinoline-1ylquinoline-carboxylate Copper (II) Chloride Hexahydrate,” Journal of Inorganic Biochemistry, Vol. 56, No. 4, 1994, pp. 273-282. doi:10.1016/0162-0134(94)85107-7

[10] D. Parker and A. G. Williams, "Taking Advantage of the $\mathrm{pH}$ and $\mathrm{pO} 2$ Sensitivity of a Luminescent Macrocyclic Terbium Phenanthridyl Complex," Chemical Communications, Vol. 12, No. 6, 1998, pp. 245-246. doi:10.1039/a707754h

[11] J. C. Rodriguez, B. Alpha, D. Plancherel, et al., "Photoactive Cryptands Synthesis of the Sodium Cryptates of Macrobicyclic Ligands Containing Bipyridine and Phenathroline groups,” Helvetica Chimica Acta, Vol. 679, No. 3, 1984, pp. 2264-2269. doi:10.1002/hlca.19840670833

[12] K. I. Kobrakov1, I. I. Rybina1, V. I. Kelarev, et al., "Halogen-Containing Pyridines Synthesis of 3,5-Dichloropyridines Containing Pyrazole and Pyrazoline Residues in Position," Chemistry of Heterocyclic Compounds, Vol. 39, No. 6, 2003, pp. 749-755.

[13] Y. Z. Qi, W. L. Fu and X. B. Zhang, "Separation, Identification and Drug Resistance of Nonfermenters," Chinese Journal of Nosocomiology, Vol. 16, No. 11, 2006, p. 1286.

[14] Y. C. Wang, X. Y. Cheng and H. Y. Guo, "Recent Progress on Quinolone Agents in China," Chinese Journal of Pharmaceuticals, Vol. 35, No. 3, 2004, pp. 179-185. 